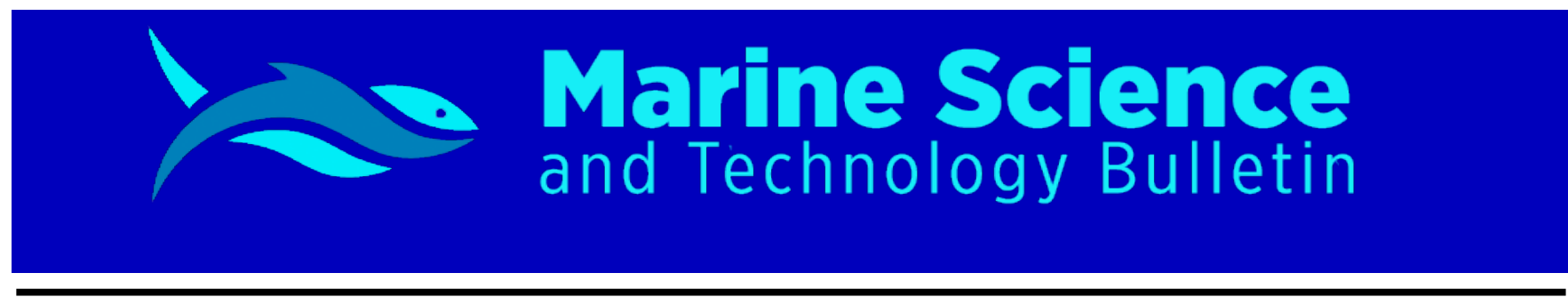

RESEARCH ARTICLE

\title{
Using of Quinoa Based Film to Extend the Shelf Life of Rainbow Trout Fillets under Cold Storage $\left(4 \pm 1^{\circ} \mathrm{C}\right)$ Condition
}

\author{
Fatih Korkmaz $^{1^{*}}$ (D) Esat Mahmut Kocaman ${ }^{1}$ (D) . Gonca Alak ${ }^{1}$ \\ ${ }^{1}$ Atatürk University, Fisheries Faculty, Erzurum, Turkey
}

\begin{abstract}
A R T I C L E I N F O
Article History:

Received: 26.11.2019

Received in revised form: 03.12.2019

Accepted: 06.12.2019

Available online: 19.12.2019

Keywords:

Quinoa

Biofilm

Trout

Fillet

Shelflife

A B S T R A C T

In this study, the structural features (thickness and light transmittance) of edible films that obtained from quinoa starch were analyzed, and the films were applied to rainbow trout fillets. These fillets were classified under two different groups without quinoa starch film (control) and coated with quinoa starch film (QSBF).Thereafter, these fillets were storage in the refrigerator at $\left(4 \pm 1^{\circ} \mathrm{C}\right)$ for 12 days. Analyzes were performed on days $0,3,9$, and 12 during storage to detect chemical and microbial changes in both groups. The film thickness was $0.195 \pm 0.010 \mathrm{~mm}$, and the light transmittance values were between $10-37 \%$. At the end of storage, the highest values of chemical analysis were found in the control group $20.35 \pm 0.49 \mathrm{mg} / 100 \mathrm{~g}$ in (TVB-N), $3.87 \pm 0.10 \mu \mathrm{mol} \mathrm{MA} / \mathrm{kg}$ in (TBARS) and $6.27 \pm 0.00$ in $(\mathrm{pH})$, respectively. The highest values of microbial analysis were found in the control group 5.35 $\pm 0.22 \mathrm{log} \mathrm{cfu} / \mathrm{g}$ in (TAMB), $3.32 \pm 0.48 \mathrm{log} \mathrm{cfu} / \mathrm{g}$ in (LAB), Pseudomonas $5.72 \pm 0.28 \mathrm{log}$ $\mathrm{cfu} / \mathrm{g}$ and Enterobacteriaceae $4.38 \pm 0.68 \mathrm{log} \mathrm{cfu} / \mathrm{g}$ in the control group respectively, although (TPC) was found $6.84 \pm 0.11 \mathrm{log} \mathrm{cfu} / \mathrm{g}$ in the QSBF group. The results of chemical and microbial analysis showed that statistical difference between control and treatment groups was significant $(\mathrm{p}<0.05)$. Quinoa starch-based biofilms (QSBF) had a chemically and microbiologically protective effect on trout fillets that were stored. Further studies are needed to optimize the use of (QSBF) as microbiological and chemical barriers for fish fillet packaging.
\end{abstract}

Please cite this paper as follows:

Korkmaz, F., Kocaman, E.M., Alak, G. (2019). Using of Quinoa Based Film to Extend the Shelf Life of Rainbow Trout Fillets under Cold Storage $\left(4 \pm 1^{\circ} \mathrm{C}\right)$ Condition. Marine Science and Technology Bulletin, 8(2): 76-84.

\section{Introduction}

Rainbow trout (Oncorhynchus mykiss) is one of the most common aquaculture fish species in the world. In recent years, the rainbow trout breeding industry has become highly developed, and its production efficiency has increased due to newly designed technological systems (Crawford and Muir, 2008). Fish and fishery-related products have been recognized as important sources of human nutrition (Masniyom,
2011). Fish-related products provide nutritional benefits due to their valuable protein content and are a significant source of polyunsaturated fatty acids. However, the quality of spoilable products, like fish meat, must be protected to ensure a long term shelf life (Dursun and Erkan, 2009). Traditional preservation methods, such as vacuum and modified atmospheric packaging, have typically been used to extend fish shelf life, although these methods require large capital investments. As an economical alternative, research has

\footnotetext{
* Corresponding author

E-mail address: korkmazf@atauni.edu.tr (F. Korkmaz)
} 
focused on the development of antimicrobial packaging systems, such as edible films or coatings that can be combined with active ingredients. Edible films and coatings can be produced from different sources including proteins, lipids and polysaccharides (Sayanjali et al., 2011). The shelf life of fish fillets has reportedly been extended from 6 to 13 days, depending on the species to which these active packaging materials have been applied (Socaciu et al., 2018). Quinoa (Chenopodium quinoa) was selected by FAO (2014) as a food safety crop for the 21st century because it is tolerant to salinity and drought stresses and can grow in marginal regions. Quinoa's high antioxidant levels and protein content make it an excellent nutrient source. However, quinoa has rarely been studied as a substrate for edible coating materials. Quinoa protein is a good biopolymer for edible films due to its excellent elongation and adhesive properties, which can be achieved without the use of plasticizers (Abugoch et al., 2011). To the best of our knowledge, the application of edible film derived from quinoa seed has not been previously reported, particularly to extend the shelf life of rainbow trout fillets. Therefore, this study aimed to evaluate the efficacy of quinoa-based edible films for increasing the shelf life of rainbow trout fillets.

\section{Material and Methods}

\section{Materials}

Rainbow trout (Oncorhynchus mykiss L., 1758) that were obtained from the Atatürk University Faculty of Fisheries, Inland Fisheries Research and Production Center were used in this study. The trout had an average weight of $300 \pm 15 \mathrm{~g}$. White quinoa (Chenopodium quinoa) from a commercial company (Damietta Gold (500 g), Turkey) was used as the film base material.

\section{Methods}

\section{Obtaining of Quinoa Starch and Films}

Quinoa seeds were soaked in a 1:2 ratio in pure water for 8 hours and then milled using a blender. The supernatants were removed by passing the milled portions through fine mesh sieves. The remaining material was placed in centrifuge tubes and centrifuged three times at $1000 \mathrm{~g}$ for 15 minutes at $4^{\circ} \mathrm{C}$, with the supernatants removed after each centrifuge. At the end of the process, the solution $\mathrm{pH}$ was adjusted to 10.5 with $0.20 \%$ aqueous $\mathrm{NaOH}$ to dissolve the remaining proteins. Then, $1 \mathrm{~mol} \mathrm{~L}^{-1} \mathrm{HCL}$ was added to neutralize the solution. After neutralization, the remaining material was washed five times with distilled water to remove the protein and salts from the solution, leaving the starch (Araujo-Farro et al., 2010). The films were prepared using the method reported by Araujo-Farro et al., (2010), with minor changes. The quinoa starch obtained in the sterile cabinet was placed in glassware at a concentration of $4 \mathrm{~g} / 100 \mathrm{~mL}$ to form film solutions. After stirring for 5-10 minutes in the magnetic stirrer to achieve saturation, the solution was left in a water bath at $82^{\circ} \mathrm{C}$ for 30 minutes until the solution achieved a plastic consistency. After standing, $1 \%$ glycerol (glycerol approx. 87\%) was added to the solution, and it was remixed with a magnetic stirrer, followed by incubation at $35^{\circ} \mathrm{C}$ for 16 hours to obtain films.

\subsubsection{Preparation and Wrapping of Fillets with Film and} Trial Plan

The fish were prepared in the laboratory using sterile scalpels to open and remove the internal organs and to clean the dorsal and abdominal muscles from the gill caps to the tail fins. The process was repeated by inverting the fish; the fillets were obtained by separating the bones, tail and gills together with their heads. For wrapping of fillets, care was taken to cover the entire surface of the fillets with films prepared under sterile conditions (Ahmad et al., 2012). Trout fillets coated under vacuum aspirator in sterile environment were placed on aluminum foils. Edible films were prepared from starches (4\% quinoa$100 \mathrm{~mL}$ distilled water-1\% glycerol) from Quinoa (C. quinoa) seeds. The prepared films were subjected to some structural (film thickness and light transmittance) analyzes. Fillets (120 pieces) are extracted from 60 trout, around $18 \mathrm{~kg}$, 60 fillets were covered with films and the rest of them were accepted as control group without any treatment and the experiment was designed repetition. The treatment and control group fillets were subjected to chemical and microbiological analyzes on certain days $\left(0,3,6,9\right.$ and 12 days) of storage at $4 \pm 1{ }^{\circ} \mathrm{C}$.

\section{Structural Analysis of Quinoa Films}

\section{Thickness measurements of edible films}

The film thickness was measured with a micrometer (Tronic, model 1131-150/Japan) with sensitivity of $0.001 \mathrm{~mm}$. Measurements were made from 10 different regions of the films and the overall average was calculated.

UV-VIS absorption spectroscopy of edible films

Light absorption measurement of edible film coatings was carried out with a UV-VIS spectrophotometer (Perkin-Elmer, model Lamda $35 /$ USA) having wavelength range of 200-1100 nm. In our study, quinoa starch edible film sample was placed into solid sample chamber and absorption spectra between 200-1100 wavelengths were taken. Light absorption values were then calculated using the equation given below.

$$
\text { Absorbance }(A)=\log \frac{I_{0}}{I}
$$

In this formula, $\mathrm{A}$; absorbance, $\mathrm{I}_{0}$; intensity of light on the sample, I; the intensity of the light leaving the sample, $\varepsilon$; molar absorption coefficient $(\mathrm{L} / \mathrm{mol}, \mathrm{cm}), \mathrm{b}$; thickness of the sample cup $(\mathrm{cm}), \mathrm{c}$; and the concentration $(\mathrm{mol} / \mathrm{L})$. The ratio between light and light intensities entering the sample cup is expressed as transmittance (T) and calculated by the following formula (Arık et al., 2005).

$$
\text { Transmittance }(T)=\frac{I_{0}}{I}=10^{-\varepsilon b c}
$$

\section{Chemical Analysis}

Total volatile basic nitrogen (TVB-N) analysis

TVB-N analysis of the samples was performed using the method reported by Malle and Tao (1987). The TVB-N value was determined by calculating formula by considering the spent $\mathrm{H}_{2} \mathrm{SO}_{4}$ solution (n) in the titration. 
Thiobarbituric acid reactive substance (TBARS) analysis

The method given by Lemon (1978) was used to determine the TBARS value. TBARS value $(\mu \mathrm{mol} \mathrm{MA} / \mathrm{kg})$ was calculated by substituting the absorbance values based on the square and the standard curve prepared with TEP $(1,1,3,3$ tetraethoxypropane) in the following formula (Aras Hisar et al., 2004).

$\mathrm{pH}$ analysis

In order to measure the $\mathrm{pH}$ values, $10 \mathrm{~g}$ of paralleled samples were taken into small pieces and $100 \mathrm{~mL}$ of purified water was added. The obtained suspensions were homogenized in Ultra-Turrax for 1-2 minutes and then measured with $\mathrm{pH}$ meter (Schott, Lab Star) (Gökalp et al. 2001).

\section{Microbiological Analysis}

Microbial analysis was carried out from cold-stored fillets were done for each bacteria group (total aerobic mesophilic, psychrotrophic, lactic acid, Pseudomonas and Enterobacteriaceae). 10 $\mathrm{g}$ fillet samples was taken and diluted in $99 \mathrm{~mL}$ of $0.85 \%(\mathrm{w} / \mathrm{v})$ sterile saline solution. To homogenise, a Stomacher (Lab. Stomacher Blander 400 BA 7021, Sward medical) was used the samples in a sterile polyethylene bag for $1.5 \mathrm{~min}$ and sterile $9 \mathrm{~mL} 0.85 \%$ (w/v) $\mathrm{NaCl}$ solution for dilution. The number of total aerobic mesophilic bacteria (TAMB; Merck, at $30 \pm 1^{\circ} \mathrm{C}$ for $48 \mathrm{~h}$; Harrigan, 1998); lactic acid bacteria (in MRS; Merck, at $30^{\circ} \mathrm{C}$ for $48 \mathrm{~h}$ in anaerobic conditions; Papamanoli et al., 2003), Pseudomonas counts were determined using Pseudomonas agar base (Oxoid) supplemented with C-FC (CetrimideFucidin-Cephloridine) selective supplement (Oxoid) incubated at $25^{\circ} \mathrm{C}$ for $48 \mathrm{~h}$. PCA plates were then incubated for 7 days at $10^{\circ} \mathrm{C}$ for psychrotorophic bacteria count (González-Fandos et al. 2005). Enterobacteriaceae (Violet Red Bile Agar, Oxoid and Violet Red Bile Dextrose Agar, Merck 1.10275.0500, at $37^{\circ} \mathrm{C}$ for $24 \mathrm{~h}$; Harrigan, 1998) were counted, respectively.

\section{Statistical Analysis}

The data obtained as a result of the experiments were subjected to variance analysis using SPSS package program (SPSS 20 Software, USA) and Duncan multiple comparison test was applied for the applications that were found to be significantly different according to the results of this analysis. Logarithmic transformation was applied to microbiological values.

\section{Results}

\section{Structural Results of Quinoa Films}

The thickness of the films obtained from the quinoa starch we used in our study was determined as $0.195 \pm 0.010 \mathrm{~mm}$. The light transmittance values of the films obtained from the quinoa starch at different wavelengths were given in Figure 1. The light transmittance of the quinoa starch edible films was $10 \%$ at $220 \mathrm{~nm}, 26 \%$ at $400 \mathrm{~nm}$, $30 \%$ at $600 \mathrm{~nm}, 34 \%$ at $800 \mathrm{~nm}$ and $37 \%$ at $1000 \mathrm{~nm}$, respectively.

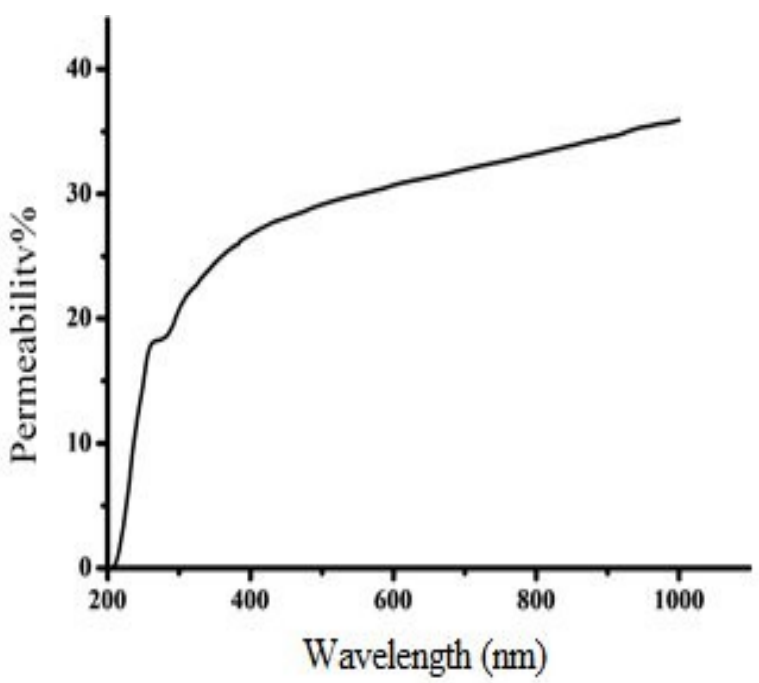

Figure1. Light transmittance values of quinoa starch edible films in different wavelength $(\mathrm{nm})$

\section{Chemical Analysis}

\section{Total volatile basic nitrogen $(T V B-N)$}

TVB-N content of rainbow trout fillets coated with quinoa starch film (QSBF) and without quinoa starch film (control) during storage is shown in Figure 2A. At the beginning of storage, TVB-N results in the control and film coating groups were $13.85 \pm 0.63 \mathrm{mg} / 100 \mathrm{~g}$. Increases were recorded in both groups up to the end of storage depending on storage time and the highest value was found $20.35 \pm 0.49$ $\mathrm{mg} / 100 \mathrm{~g}$ in the control group and $18.65 \pm 0.21 \mathrm{mg} / 100 \mathrm{~g}$ in the QSBF group. In statistical analysis, day and group, which is one of the main sources of variation, were found very important at $\mathrm{p}<0.01$ level, while the effect of group $x$ day interaction was found significant at $p<0.05$ level.

\section{Thiobarbituric acid reactive substance (TBARS)}

TBARS results during the storage days are shown in Figure 2B. In the control and film coating groups at the beginning of storage were determined as $2.46 \pm 0.08$ and $2.76 \pm 0.28 \mu \mathrm{mol} \mathrm{MA} / \mathrm{kg}$, respectively. Increases were observed in both groups until the end of storage period, and the highest value was found to $3.87 \pm 0.10 \mu \mathrm{mol} \mathrm{MA} / \mathrm{kg}$ in the control group at the end of storage period. According to the analysis of variance, the effect of group and day, which are the main sources of variation on TBARS value, was very important $(p<0.01)$, and the effect of group $x$ day interaction was insignificant $(\mathrm{p}<0.05)$.

$$
p H
$$

$\mathrm{pH}$ values of treatment and control group is shown Figure 2C. At the beginning of storage, $\mathrm{pH}$ values of control and QSBF groups were determined as $6.27 \pm 0.00$ and $6.28 \pm 0.02$, respectively. Increases were observed in both groups until the end of the storage period. At the end of the storage period, the lowest value was found to $7.66 \pm 0.22$ in the film coated group. According to the analysis of variance, it was determined that the day was very important $(p<0.01)$, the groups were insignificant $(\mathrm{p}<0.05)$ and the effect of group $\mathrm{x}$ day interaction was significant $(\mathrm{p}<0.05)$. 


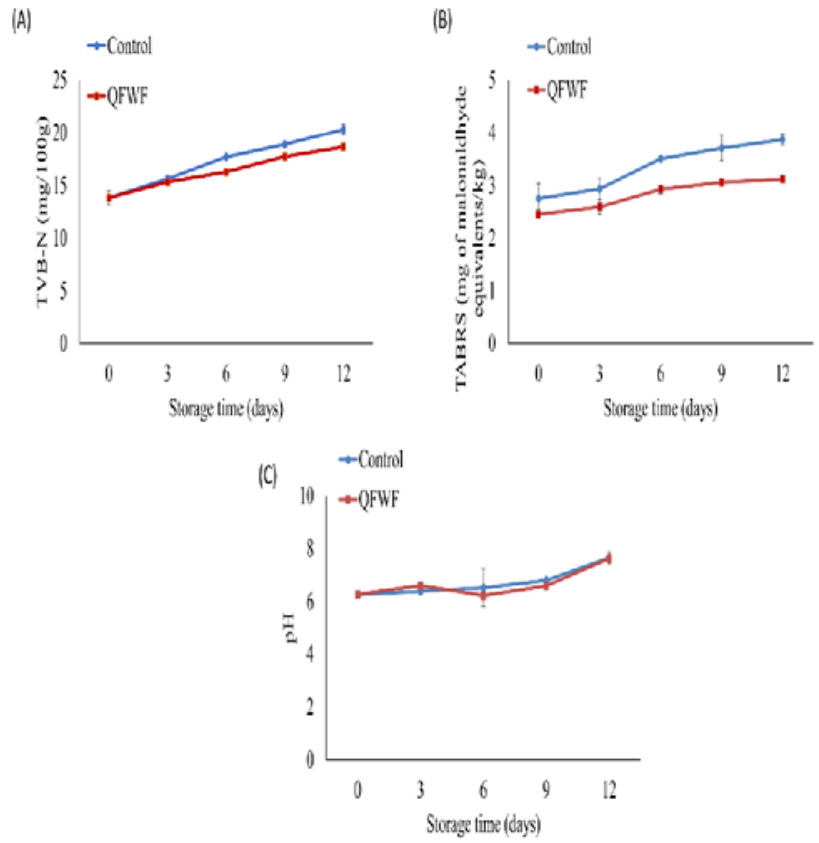

Figure 2. The effect of edible coating with on (A); Total volatile basic nitrogen (TVB-N), (B); Thiobarbituric acid reactive substance (TBARS), (C); $p H$ values of trout fillets during storage (12 day) at $4 \pm$ $1^{\circ} \mathrm{C}$. Mean \pm standard deviation of the values (three replicates) are presented

\section{Microbiological load of filmed trout fillets}

The results of the number of bacteria determined during storage (12 days) were given in Figure 3. The total number of aerobic mesophilic bacteria (TAMB) was $2.55 \pm 0.07 \mathrm{log} \mathrm{cfu} / \mathrm{g}$ and $2.52 \pm 0.06 \mathrm{log}$ $\mathrm{cfu} / \mathrm{g}$ in the control and QSBF groups at the beginning of storage, respectively. Increases in the number of TAMB were observed in parallel with storage period and the highest value was found to $5.35 \pm 0.22 \mathrm{log} \mathrm{cfu} / \mathrm{g}$ in the control group at the end of storage period. The results showed that the effect of group and day on the TAMB was statistically very significant $(\mathrm{p}<0.01)$ and that group $\mathrm{x}$ day interaction was significant $(\mathrm{p}<0.05)$. The total number of psychrotrophic bacteria (TPC) was found to $4.19 \pm 0.71 \mathrm{log} \mathrm{cfu} / \mathrm{g}$ in both groups at the beginning of storage in Figure 3. Continuous increase in these values was observed during storage and the highest value was found to $6.84 \pm 0.11 \mathrm{log} \mathrm{cfu} / \mathrm{g}$ in QSBF group at the end of storage period. The results showed that the effect of group and day on the number of psychrotrophic bacteria was statistically significant $(p<0.01)$, and that the interaction of group $x$ days was insignificant $(p<0.05)$. The number of LAB at the first day of storage was found $2.00 \pm 0.00 \mathrm{log} \mathrm{cfu} / \mathrm{g}$ in the control and QSBF group in Figure 3. During the storage period, no change was observed in both groups and the highest value at the end of storage period was found $3.32 \pm 0.48$ and $2.66 \pm 0.28$ in the control and QSBF group, respectively. After the statistical analysis, it was determined that the effect of groups $(p<0.05)$ and the effect of days and group $\mathrm{x}$ days interaction on lactic acid bacteria number $(\mathrm{p}<0.01)$ was significant. At the beginning of storage, the number of Pseudomonas in the control and film coating group was $2.00 \pm 0.00 \mathrm{log}$ $\mathrm{cfu} / \mathrm{g}$ in Figure 3. Increases were observed in both groups until the end of storage period, the highest value at the end of storage period was $5.72 \pm 0.28 \mathrm{log} \mathrm{cfu} / \mathrm{g}$ in the control group and 5.23 $\pm 0.22 \mathrm{log} \mathrm{cfu} / \mathrm{g}$ in
QSBF group. In statistical analysis, the difference between storage days was significant for both groups $(\mathrm{p}<0.05)$. According to the analysis of variance, the effect of group $\mathrm{x}$ day interaction was significant $(\mathrm{p}<0.05)$ and days were very significant $(\mathrm{p}<0.01)$. The number of Enterobacterieacea at the beginning of storage was found to same value $2.00 \pm 0.00 \mathrm{log} \mathrm{cfu} / \mathrm{g}$ in the control and film coating group in Figure 3. Increases were observed in both groups until the end of storage period. On the last day of storage, the highest values $(4.38 \pm 0.68 \log \mathrm{cfu} / \mathrm{g})$ were observed in the control group and $4.07 \pm 0.54 \mathrm{log} \mathrm{cfu} / \mathrm{g}$ in the QSBF group. According to the analysis of variance, the effect of group and group $\mathrm{x}$ day interaction on the number of Enterobacterieacea was insignificant $(\mathrm{p}<0.05)$ and the difference between days was significant $(\mathrm{p}<0.01)$.
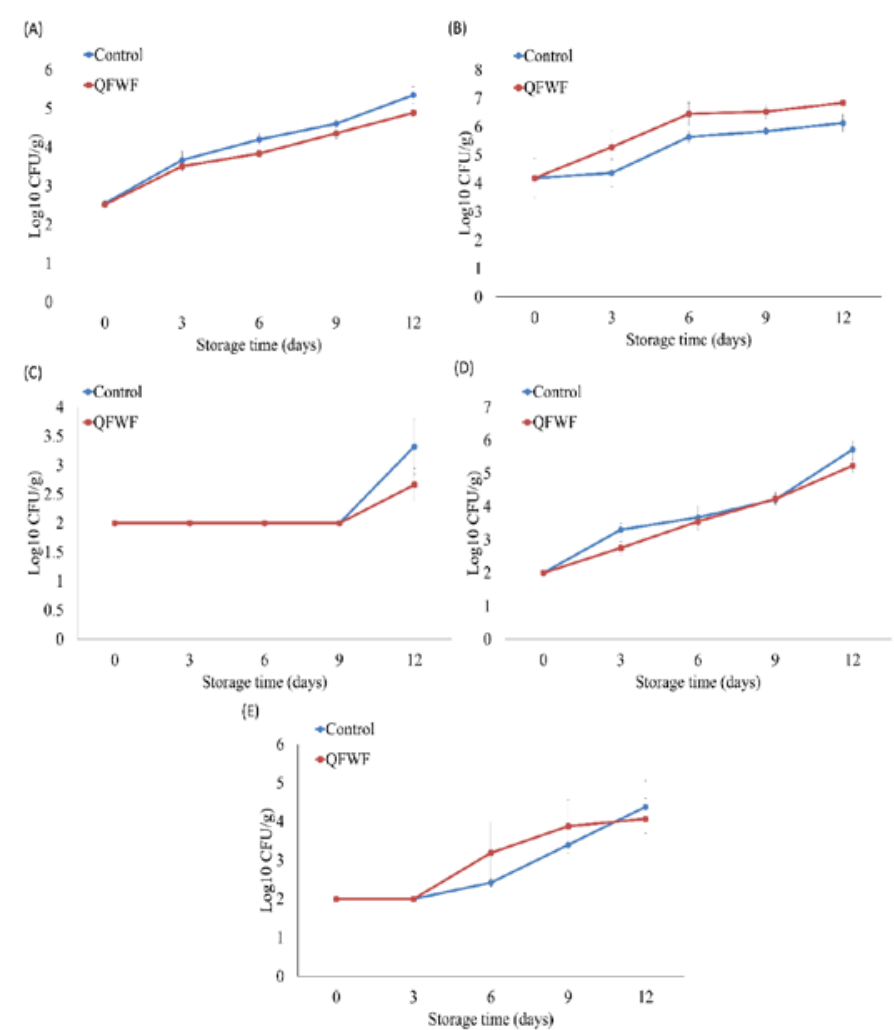

Figure 3. The effect of edible coating with on (A); The total number of aerobic mesophilic bacteria (TAMB) (B); Total psychrotrophic bacteria (TPB), (C); Lactic acid bacteria (LAB), (D); Pseudomonas, (E); Enterobacterieacea values of trout fillets during storage (12 day) at $4 \pm$ $1^{\circ} \mathrm{C}$. Mean \pm standard deviation of the values (five replicates) are presented

\section{Discussion}

Structural Properties of Quinoa (Chenopodium quinoa)

\section{Films}

In our study, we measured the thickness of films as $0.195 \pm 0.010$ $\mathrm{mm}$. The difference in film thickness may vary depending on the bulk thickness, the difference of the main material used in the production of the film, the amount of use of the materials and the mixing ratios. Therefore, it is clear that other studies do not show similarity. In a study, which investigated the properties of gelatin films with seaweed extract, it was reported that the average thickness of films containing 
gelatin film and gelatin-seaweed extract was $0.295 \mathrm{~mm}$ (Rattaya et al., 2009). Valenzuela et al., (2013) reported the film thicknesses as $0.051 \pm 0.001,0.110 \pm 0.009,0.111 \pm 0.010$ and $0.126 \pm 0.008 \mathrm{~mm}$ in a study in which they determined the characterization and structure of edible biofilms consisting of a mixture of quinoa protein-chitosansunflower oil. In another study, the characterization of edible biofilms with quinoa protein-chitosan mixture was investigated and the thicknesses of the films were reported as $0.142 \pm 0.017,0.125 \pm 0.017$ and $0.054 \pm 0.003 \mathrm{~mm}$ (Abugoch et al., 2011). Araujo-Farro et al., (2010) have identified the thickness of films containing quinoa starch as $0.080 \pm 0.020 \mathrm{~mm}$. UV-VIS Absorption Spectroscopy has been found that \% light transmittance increases parallel to the increase of light wavelength. Gomez-Guillen et al., (2007) and (Al-Hassan and Norziah 2012) reported that the transparency of the films is very important on the light transmittance of the edible films, and that this transparency may be related to the addition of any material to the main materials used. Similarly, in our study, it was found that the quinoa starch used in the film production was quite light and therefore the light transmittance values differed from other studies due to the transparent color of the films obtained.

\section{Chemical Changes of Filmed Trout Fillets}

The TVB-N is very usually used in the assignation of spoilage of seafood (Ruiz-Capillas and Moral, 2001). It describes the sum of ammonia, methylamine, dimethylamine, trimethylamine, and other basic nitrogenous volatile compounds resulted from fish degradation (Sikorski, 1990; Ruiz-Capillas et al., 2015). As a result of endogenous enzyme and bacterial activities in fish, the amount of volatile basic nitrogenous substances increases. The acceptable limit values (25 mg/100 g) of TVB-N (Aras Hisar et al., 2004) vary according to the fish species, but the data obtained in our study are among the mentioned limit values (Nowzari et al., 2013; Volpe et al., 2015). The daily consumable limit value determined for trout was reported as 20 mg/100g by Aras Hisar et al., (2004) and Alak, (2012). At the beginning, TVB-N value was found as $13.85 \pm 0.63 \mathrm{mg} / 100 \mathrm{~g}$ in our study. Parallel results were also published by another researchers in different works about on ice stored $S$. aurata (Tejada and Huidobro, 2002; Grigorakis et al., 2003; Kilinc et al., 2007). In our study, TVB-N values obtained from the control and QFW fillets remained below the daily consumable limit value during the storage period. Morover, the lowest value was found $18.65 \pm 0.21 \mathrm{mg} / 100 \mathrm{~g}$ in the QSBF group at the end of storage. That value suggested that coating with QSBF may cause delaying the increase of the TVB-N value. This result can shows that the TVB-N results are related to microbiological findings. Similar results were also published by different researchers (Fan et al., 2009; Gómez-Estaca et al., 2010; Ojagh et al., 2010; Alak et al., 2010; Li et al., 2013). Morover, Ucak (2019) was reported that the TVB-N values reached 42.70, 39.90, 34.30 and $30.10 \mathrm{mg} \mathrm{N} / 100 \mathrm{~g}$ in control, G0 (samples wrapped with gelatin film), G4 (samples wrapped with gelatin film incorporated with $4 \%$ garlic peel extract) and G8 groups (samples wrapped with gelatin film incorporated $8 \%$ with garlic peel extract), respectively at the end of the storage. When the results of our study are compared with other studies, it is seen that fish species, storage conditions, processing technologies, additives and packaging are effective in TVB-N value used as freshness criteria (Alak, 2012;
Aras Hisar et al., 2004). Lipid oxidation is an important issue for quality of food. Because of TBARS is generally a significant parameter used as lipid oxidation index (Fan et al., 2009; Jeon et al., 2002; Jongjareonrak et al., 2008; Ojagh et al., 2010). Some researchers (Ojagh et al., 2010; Jouki et al., 2014; Shokri and Ehsani 2017), were published that values $<3 \mathrm{mg} \mathrm{MDA} / \mathrm{kg}$ for perfect quality material, $<5$ for good quality material, and $5 \leq \mathrm{MDA} / \mathrm{kg}<8$ for suitable for human consumption. It has been reported that edible biofilms can be an important barrier in preventing light-effect lipid oxidation on foods (Gómez-Estaca et al., 2009). Furthermore, it is thought to be effective in decreasing oxidation level in the coated fillets by preventing the contact between food and oxygen due to the barrier properties of the films. In addition, fish species, preservative application, storage conditions and packaging may have an impact on TBARS values (Araujo-Farro et al., 2010). In our current study results, it was also determined that quinoa film coating applied during storage period had inhibitory effect on lipid oxidation. Because of the highest value was found $3.87 \pm 0.10 \mu \mathrm{mol} \mathrm{MA} / \mathrm{kg}$ in the control group at the end of storage day. Similarly, (Sathivel et al., 2007) reported that chitosan and soy protein concentrate delays lipid oxidation in skinless pink salmon fillets. Ucak (2019) sum up lipid oxidation was also delayed in the samples wrapped with gelatin films incorporated with garlic acid extract, especially in concentration of $8 \%$. In parallel with, (Socaciu et al., 2018), were published data reviewed in the theirs paper that TBARS values ranged from 0.2 to $0.9 \mathrm{mg} \mathrm{MDA} / \mathrm{kg}$ for rainbow trout fillets, 1.1 to $1.8 \mathrm{mg} \mathrm{MDA} / \mathrm{kg}$ for salmon fillets, 1.0 to $2.5 \mathrm{mg} \mathrm{MDA} / \mathrm{kg}$ for pikeperch fillets, 0.06 to $0.12 \mathrm{mg} \mathrm{MDA} / \mathrm{kg}$ for beluga sturgeon fillets, 3.0 to $4.0 \mathrm{mg} \mathrm{MDA} / \mathrm{kg}$ for silver carp fillets, 0.9 to $1.2 \mathrm{mg} \mathrm{MDA} / \mathrm{kg}$ for grass carp fillets, 0.2 to $2.0 \mathrm{mg} \mathrm{MDA} / \mathrm{kg}$ for Japanese sea bass fillets, and 0.8 to $1.8 \mathrm{mg} \mathrm{MDA} / \mathrm{kg}$ for red drum fillets. Owing to accumulation of alkaline compounds indicating fish spoilage, $\mathrm{pH}$ of trout fillets increased slowly during our study (Utami et al., 2014). Fan et al., (2009) investigated the effect of chitosan coating on the quality and shelf life of silver carp and found that the $\mathrm{pH}$ value of chitosan coated products was lower than the control group. In different studies with biofilm coating, it was also reported that the $\mathrm{pH}$ value was low (Gómez-Estaca et al., 2009; Volpe et al., 2015). The initial low level of $\mathrm{pH}$ in fish is due to the conversion of glycogen to lactic acid during the post mortem glycolysis phase (Sengor et al., 2000). In the next stage, the oxidation-reduction equilibrium, the change in the concentration of free hydrogen and hydroxyl ions occur due to the increase of storage time and the effect of enzyme-microorganisms and thus the $\mathrm{pH}$ value increases. In addition, decomposition of nitrogenous compounds in meat due to post-mortem changes leads to an increase in $\mathrm{pH}$ (Hernández et al., 2009). In our study, $\mathrm{pH}$ was determined that the day was very important $(\mathrm{p}<0.01)$, the groups were insignificant $(\mathrm{p}>0.05)$. Similarly, (Dogan and Izci, 2015) were published that the $\mathrm{pH}$ values were observed as increase, although chitosan film coated fillets was lower than the control group $(\mathrm{P}<0.05)$. It was observed that the data obtained in our study was consistent with the researches mentioned above.

\section{Microbiological Load of Filmed Trout Fillets}

There are many studies on the storage of fish and other aquaculture products with antimicrobial properties of edible coatings 
in the literature. Because of microbiological analysis is very important for determining the quality of the food products. In the literature, the values of TAMB in fresh fish have been reported by different researchers as 2-7 log cfu/g (Sallam, 2007; Song et al., 2011). In our study, we found that the number of bacteria in all groups increased during storage. But the limit value (7 log cfu/g) was not exceeded in control and QFW groups at the end of on storage. Our data, which is in parallel with the results of a lot studies where the same storage process and different film techniques are applied, is thought to have a significant inhibitory effect of coating solution and coating technique on the TAMB. Some researchers also informed these coatings have antimicrobial effect (Vásconez et al., 2009; Alak et al., 2010; Zhou et al., 2011; Qiu et al., 2014; Bahram et al., 2016; Y1ldız and Yangllar, 2016; Shokri and Ehsani, 2017). Ahmad et al., (2012) documented that gelatin film integrated with lemongrass essential oil may reduced microbial counts of sea bass slices. Similarly, (Lu et al., 2010) reported that TAMB of coated sample was $5.27 \mathrm{log} \mathrm{cfu} / \mathrm{g}$ on the contrary that of control sample reached $8.10 \mathrm{log} \mathrm{cfu} / \mathrm{g}$ on fresh northern snakehead fish fillets during refrigeration storage. Edible coatings (Souza et al., 2010), was applied to salmon fillets and (Feng et al., 2016) golden pomfret fillets respectively, showed an antimicrobial impact compared to uncoated groups. In paralled with salmon fillets without any coating surpassed the critic level ( $7 \mathrm{log} \mathrm{cfu} / \mathrm{g}$ ) on the 12 day, (Souza et al., 2010). TPB results obtained at the end of storage period is not consistent with the results reported by ( Ojagh et al., 2010; Jiang et al., 2011; Ahmad et al., 2012; Huang et al., 2012; Cardoso et al., 2017). It is thought that the variation of the film materials used is effective in this change. Similarly, Dursun (2012) stated that protein film coating may cause a decrease or increase in the number of psychrotrophic bacteria. This situation is in parallel with our study data. In addition, the difference of fish material can be effective in the determined mismatch. Alak (2011) reported that there may be an increase in the number of psychrotrophic bacteria in cold water fish. Facultative anaerobic $\mathrm{LAB}$ are the main cause of meat spoilage. Particular species of LAB (such as Lactobacillus spp., Carnobacterium spp. and Leuconostoc spp.) have been reported as the most effective bacteria in meat spoilage (Giatrakou et al., 2010). The highest values were found $3.32 \pm 0.48$ and $2.66 \pm 0.28$ in the control and QSBF group, respectively, at the end of storage period on LAB. Similar results were obtained in different film-coating studies (No et al., 2002; Viuda and Martos et al., 2008; Volpe et al., 2015; Carrión-Granda et al., 2018). In particular, it is known that solvent material and biofilm additives are effective in inhibiting lactic acid bacteria (Volpe et al., 2015; Yıldız and Yangilar 2016; Carrión-Granda et al., 2018). Kazemi and Rezaei (2015), the lowest amounts of LAB count published in the samples coated at first and last days of storage, respectively. In the present study, when the lactic acid bacteria numbers of the control and film coating groups were examined on the last day of storage, these numbers were found that the application had an inhibitory effect on the bacteria. Gram negative psychrotrophic bacteria are the major group of microorganisms responsible for aerobically spoilage of fresh fish at low temperatures and Pseudomonas spp. are the main bacteria in this group (Wei et al., 2006). Different solvents and films are known to be effective in inhibiting Pseudomonas (Alak, 2012; Shokri and Ehsani 2017; Yu et al., 2017). Gómez-Estaca et al., (2009) determined that antimicrobial effect of clove essential oil added, fish gelatin and chitosan composite films on Lactobacillus acidophilus, Pseudomonas fluorescens, Listeria innocua and Escherichia coli bacteria. We also obtained similar result that was $5.72 \pm 0.28 \mathrm{log} \mathrm{cfu} / \mathrm{g}$ in the control group and 5.23 $\pm 0.22 \mathrm{log} \mathrm{cfu} / \mathrm{g}$ in QSBF group in our study. Similarly, (Raeisi et al., 2015) report that the increasing in control samples was significantly higher than that of coated ones as reached to $7.4 \mathrm{log} \mathrm{cfu} / \mathrm{g}$ at day 10. Nirmal et al., (2009) reported that the application of sodium metabisulfite and catesin is effective on Enterobacterieacea in shrimps and that sodium metabisulfite shows low inhibition properties. Lee and Yoon (2001) reported that acids released by lactic acid bacteria in materials applied may inhibit Enterobacterieacea bacteria. Edible coating with $8 \%$ whey protein concentrate/glycerol, 2:1 has also shown to be effective against Enterobacteriaceae in rainbow trout fillets as compared with the other formulations tested in the study (Yıldiz and Yangllar 2016). The most effective edible films/coatings against Enterobacteriaceae were those incorporated with 2\% thyme esential oil (Jouki et al., 2014) 1.5\% oregano (Kazemi and Rezaei 2015) and $1 \%$ lemon (Volpe et al., 2015) that were applied on rainbow trout fillet. The data obtained in our study show similarity with the results of the researchers.

\section{Conclusion}

Studies on the effects of edible biofilms obtained from starch extracts from Quinoa seeds on food shelf life have been found to be quite limited. In the literature review, studies related to this substance have not been found, especially in seafood processing technology. However, in recent years, there has been a growing interest in the use of quinoa, a dietary food, as an edible film. In this study, the structural properties (thickness and light transmittance) of the obtained quinoa biofilms and chemical and microbiological changes during cold storage in film coated fillets were investigated in order to determine the possibilities or suitability of use in rainbow trout fillets. In our study, it was determined that quinoa starch film coating applied to trout fillets had a significant effect especially on chemical parameters in cold storage and had inhibitory effect on bacterial growth. It is also thought that this application has a positive effect on trout fillet quality parameters in terms of shelf life and can be used as an alternative source of biofilm for the protection of aquatic products. In particular, it is considered that these products, which do not have a negative health effect on the seafood processing industry and which contribute positively to the nutritional content of the product, should be supported with further studies to be developed and enriched with the use of appropriate technical-technology.

\section{Acknowledgments}

This study was supported within the scope of Ataturk University Scientific Research Projects (BAP) with Project Number: 2015/184 and was produced from a M.Sc. thesis of Fatih KORKMAZ (The number of thesis; 434879).

\section{Conflict of Interest}

The authors declare that there is no conflict of interest. 


\section{References}

Abugoch, L.E., Tapia, C., Villamán, M.C., Yazdani-Pedram, M. \& Díaz-Dosque, M. (2011). Characterization of quinoa protein-chitosan blend edible films. Food Hydrocolloids, 25(5): 879-886. https://doi.org/10.1016/j.foodhyd.2010.08.008

Ahmad, M., Benjakul, S., Sumpavapol, P. \& Nirmal, N.P. (2012). Quality changes of sea bass slices wrapped with gelatin film incorporated with lemongrass essential oil. International Journal of Food Microbiology, 155: 171-178. https://doi.org/10.1016/j.ijfoodmicro.2012.01.027

Alak, G., Aras Hisar, Ş., Hisar, O., Kaban, G. \& Kaya, M. (2010). Microbiological and chemical properties of bonito fish (Sarda sarda) fillets packaged with chitosan film, modified atmosphere and vacuum. Kafkas Üniversitesi Veteriner Fakültesi Dergisi, 16(Suppl A): 73-80. https://doi.org/10.9775/kvfd.2009.1475

Alak, G. (2011). Effects of probiotics and prebiotics on some physical, chemical and microbiological properties of rainbow trout (Oncorhynchus mykiss) intestinal flora and fillets. Ph.D. Thesis, Atatürk University, Erzurum, Turkey.

Alak, G. \& Aras Hisar, Ş. (2012). The effects of probiotics and prebiotics on rainbow trout (Oncorhynchus mykiss) intestinal flora. International Journal of Aquaculture, 2(3): 11-14. https://doi.org/10.5376/ija.2012. 02.0003

Alak, G. \& Aras Hisar, Ş. (2012). The effect of chitosan prepared in different solvents on the quality parameters of brown trout fillets (Salmo trutta fario). Journal of Aquaculture, 2(3): 1114. http://doi.org/10.4236/fns.2012.39172

Al-Hassan, A.A. \& Norziah, M.H. (2012). Starch gelatin edible films: Water vapor permeability and mechanical properties as affected by plasticizers. Food Hydrocolloids, 26(1): 108-117. https://doi.org/10.1016/j.foodhyd.2011.04.015

Aras Hisar, Ş., Hisar, O., Kaya M. \& Yanik, T. (2004). Effects of modified atmosphere and vacuum packaging on microbiological and chemical properties of rainbow trout (Oncorynchus mykiss) fillets. International Journal of Food Microbiology, $\quad$ 97(2): 209-214. https://doi.org/10.1016/j.ijfoodmicro.2004.05.024

Araujo-Farro, P.C., Podadera, G., Sobral, P.J.A. \& Menegalli, F.C. (2010). Development of films based on quinoa (Chenopodium quinoa, Willdenow) starch. Carbohydrate Polymers, $\quad$ 81(4): 839-848. https://doi.org/10.1016/j.carbpol.2010.03.051

Arık, M., Çelebi, N. \& Onganer, Y. (2005). Fluorescence quenching of fluorescein with molecular oxygen in solution. Journal of Photochemistry and Photobiology A: Chemistry, 170(2): 105111. https://doi.org/10.1016/j.jphotochem.2004.07.004

Bahram, S. Rezaie, M. Soltani, M. Kamali, A. Abdollahi, M. Ahmadabad, M.K. \& Nemati, M. (2016). Effect of whey protein concentrate coating cinamon oil on quality and shelf life of refrigerated Beluga Sturegeon (Huso huso). Jotrnal of Food Quality, 39(6): 743-749. https://doi.org/10.1111/jfq.12227

Cardoso, L.G., Santos, J.C.P., Camilloto, G.P., Miranda, A.L., Druzian, J.I. \& Guimarães, A.G. (2017). Development of active films poly (butylene adipate co-terephthalate)-PBAT incorporated with oregano essential oil and application in fish fillet preservation. Industrial Crops and Products, 108: 388-397. https://doi.org/10.1016/j.indcrop.2017.06.058
Carrión-Granda, X., Fernández-Pan, I., Rovira, J. \& Maté, J.I. (2018). Effect of antimicrobial edible coatings and modified atmosphere packaging on the microbiological quality of cold stored hake (Merluccius merluccius) fillets. Journal of Food Quality, 2018: $\quad 6194906$. https://doi.org/10.1155/2018/6194906

Crawford, S.S. \& Muir, A.M. (2008). Global introductions of salmon and trout in the genus Oncorhynchus: 1870-2007. Reviews in Fish Biology and Fisheries 18: 313-344. https://doi.org/10.1007/s11160-007-9079-1

Dogan, G \& Izci, L. (2015). Effects on quality properties of smoked rainbow trout (Oncorhynchus mykiss) fillets of chitosan films enriched with essential oils. Journal of Food Processing and Preservation, $\quad \mathbf{4 1}(1)$ : https://doi.org/10.1111/jfpp.12757

Dursun, O.S. (2012). The effect of edible protein film coating on the quality and shelf life of smoked fish. PhD Thesis. İstanbul University, İstanbul, Turkey.

Dursun, S. \& Erkan, N. (2009). The use of edible protein films in seafood. Journal of FisheriesSciences.com, 3(4): 352-373. https://doi.org/10.3153/jfscom.2009040

Fan, W., Sun, J., Chen, Y., Qiu, J., Zhang, Y. \& Chi, Y. (2009). Effects of chitosan coating on quality and shelf life of silver carp during frozen storage. Food Chemistry, 115: 66-70. https://doi.org/10.1016/j.foodchem.2008.11.060

FAO. (2014). Hundred and forty-ninth session. Assessment of the international year of quinoa 2013, Rome, Italy.

Feng, X., Bansal, N. \& Yang, H. (2016). Fish gelatin combined with chitosan coating inhibits myofibril degradation of golden pomfret (Trachinotus blochii) fillet during cold storage. Food Chemistry, 200: 283-292. https://doi.org/10.1016/j.foodchem.2016.01.030

Giatrakou, V., Ntzimani, A., Zwietering, M. \& Savvaidis, I.N. (2010). Combine chitosan-thyme treatments with modified atmosphere packaging on a Greek ready to cook (RTC) poultry product. Journal of Food Protection, 73(4): 663-669. https://doi.org/10.4315/0362-028X-73.4.663

González-Fandos, E., Villarino-Rodríguez, A., García- Linares, M.C., García-Arias, M.T., García-Fernández, M.C. (2005). Microbiological safety and sensory characteristics of salmon slices processed by the sous vide method. Food Control, 16: 77-85. https://doi.org/10.1016/j.foodcont.2003.11.011

Gómez-Estaca, J., López, de Lacey, A., Gómez-Guillén, M.C., LópezCaballero, M.E. \& Montero, P. (2009). Antimicrobial activity of composite edible films based on fish gelatin and chitosan incorporated with clove essential oil. Journal of Aquatic Food Product Technology, 18(1-2): 46-52. https://doi.org/10.1080/10498850802581252

Grigorakis, K., Taylor, K.D.A. \& Alexis, M.N. (2003). Seasonal patterns of spoilage of ice-stored cultured gilthead sea bream (Sparus aurata). Food Chemistry, 81(2): 263-268. https://doi.org/10.1016/S0308-8146(02)00421-1

Harrigan, W.F. (1998). Laboratory methods in food microbiology. 3rd Ed., San Diego, California, USA.

Hernández, M.D., López, M.B., Álvarez, A., Ferrandini, E., García García, B. \& Garrido, M.D. (2009). Sensory, physical, chemical and microbiological changes in aquacultured meagre (Argyrosomus regius) fillets during ice storage. Food Chemistry,

114: 237-245. https://doi.org/10.1016/j.foodchem.2008.09.045

Huang, J., Chen, Q., Qiu, M. \& Li, S. (2012). Chitosan-based edible coatings for quality preservation of postharvest whiteleg 
shrimp (Litopenaeus vannamei). Journal of Food Science, 77(4): C491-C496. https://doi.org/10.1111/j.1750$\underline{3841.2012 .02651 . \mathrm{X}}$

Jeon, Y.-J., Kamil, J.Y. \& Shahidi, F. (2002). Chitosan as an edible invisible film for quality preservation of herring and Atlantic cod. Journal of Agricultural and Food Chemistry, 50(18): 5167-5178. https://doi.org/10.1021/jf0116931

Jiang, M., Liu, S. \& Wang, Y. (2011). Effects of antimicrobial coating from catfish skin gelatin on quality and shelf life of fresh white shrimp (Penaeus vannamei). Journal of Food Science, 76: M204-M209. https://doi.org/10.1111/j.1750$\underline{3841.2011 .02056 . \mathrm{x}}$

Jongjareonrak, A., Benjakul, S., Visessanguan, W. \& Tanaka, M. (2008). Antioxidative activity and properties of fish skin gelatin films incorporated with BHT and $\alpha$-tocopherol. Food Hydrocolloids, 22(3): 449-458. https://doi.org/10.1016/j.foodhyd.2007.01.002

Jouki, M., Yazdi, F.T., Mortazavi, S.A., Koocheki, A. \& Khazaei, N. (2014). Effect of quince seed mucilage edible films incorporated with oregano or thyme essential oil on shelflife extension of refrigerated rainbow trout fillets. International Journal of Food Microbiology, 174: 88-97. https://doi.org/10.1016/j.ijfoodmicro.2014.01.001

Kazemi, S.M. \& Rezaei, M. (2015). Antimicrobial effectiveness of gelatin-alginate film containing oregano essential oil for fish preservation. Journal of Food Safety, 35(4): 482-490. https://doi.org/10.1111/jfs.12198

Kilınc, B., Caklı, S., Cadun, A., Dincer, T. \& Tolasa, S. (2007). Comparison of effects of slurry ice and flake ice pretreatments on the quality of aquacultured sea bream (Sparus aurata) and sea bass (Dicentrarchus labrax) stored at $4^{\circ} \mathrm{C}$. Food Chemistry, 104(4): 1611-1617. http://dx.doi.org/10.1016/j.foodchem.2007.03.002

Lee, K.-T. \& Yoon, C.-S. (2001). Quality changes and shelf life of imported vacuum-packaged beef chuck during storage at $0^{\circ} \mathrm{C}$. Meat $\quad$ Science, $\quad$ 59(1): $\quad$ 71-77. https://doi.org/10.1016/S0309-1740(01)00054-7

Lemon, D.W. (1975). An improved TBA test for rancidity. New Series Circular, Halifax, Nova Scotia.

Li, T., Li, J., Hu, W. \& Li, X. (2013). Quality enhancement in refrigerated red drum (Sciaenops ocellatus) fillets using chitosan coatings containing natural preservatives. Food Chemistry, 138(2-3): 821-826. https://dx.doi.org/10.1016/j.foodchem.2012.11.092

Lu, F., Ding, Y., Ye, X. \& Liu, D. (2010). Cinnamon and nisin in alginate calcium coating maintain quality of fresh northern snakehead fish fillets. LWT - Food Science and Technology, 43(9): 1331-1335. https://doi.org/10.1016/j.lwt.2010.05.003

Malle, P. \& Tao, S.H. (1987). Rapid quantitative determination of trimethylamine using steam distillation. Journa of Food Protection, 50(9): 756-760. https://doi.org/10.4315/0362$\underline{028 \mathrm{x}-50.9 .756}$

Masniyom, P. (2011). Deterioration and shelf-life extension of fish and fishery products by modified atmosphere packaging, Songklanakarin Journal of Science Technology, 33(2): 181192.

Nirmal, N.P. \& Benjakul, S. (2009). Melanosis and quality changes of Pacific white shrimp (Litopenaeus vannamei) treated with catechin during iced storage. Journal of Agricutural and Food Chemistry, $\quad 57(9):$ https://doi.org/10.1021/jf900051e
No, H.K., Young, Park, N., Ho, Lee, S. \& Meyers, S.P. (2002). Antibacterial activity of chitosans and chitosan oligomers with different molecular weights. International Journal of Food Microbiology, 74(1-2): 65-72. https://doi.org/10.1016/S0168-1605(01)00717-6

Nowzari, F., Shábanpour, B. \& Ojagh, S.M. (2013). Comparison of chitosan-gelatin composite and bilayer coating and film effect on the quality of refrigerated rainbow trout. Food Chemistry, 141(3): 1667-1672. https://doi.org/10.1016/j.foodchem.2013.03.022

Ojagh, S.M., Rezaei, M., Razavi, S.H. \& Hosseini, S.M.H. (2010). Effect of chitosan coatings enriched with cinnamon oil on the quality of refrigerated rainbow trout. Food Chemistry, 120(1): https://doi.org/10.1016/j.foodchem.2009.10.006

193-198.

Papamanoli, E., Tzanetakis, N., Litopoulou Tzanetakin, E. \& Kotzekidou, P. (2003). Characterization of lactic acid bacteria isolated from a Greek dry-fermented sausage in respect of their technological and probiotic properties. Meat Science, 65(2): 859- 867. https://doi.org/10.1016/S03091740(02)00292-9

Raeisi, M., Tajik H., Aliakbarlu, J., Mirhosseini, S.H. \& Hosseini, S.M.H. (2015). Effect of carboxymethyl cellulose-based coatings incorporated with Zataria multiflora Boiss. Essential oil and grape seed extract on the shelf life of rainbow trout fillets. LWT - Food Science and Technology, 64(2): 898-904. https://doi.org/10.1016/j.lwt.2015.06.010

Rattaya, S., Benjakul, S. \& Prodpran, T. (2009). Properties of fish skin gelatin film incorporated with seaweed extract. Journal of Food Engineering, 95(1): 151-157. https://doi.org/10.1016/j.jfoodeng.2009.04.022

Robles-Martinez, C., Cervantes, E. \& Ke, P.J. (1982). Recommended method for testing the objective rancidity development in fish based on TBARS formation Canadian Technical Report of Fisheries and Aquatic Sciences No. 1089. 27p.

Ruiz-Capillas, C. \& Moral, A. (2001). Correlation between biochemical and sensory quality indices in hake stored in ice. Food Research International, 34(5): 441-447. https://doi.org/10.1016/S0963-9969(00)00189-7

Ruiz-Capillas, C. Herrero, A.M. \& Jiménez-Colmenero, F. (2015) Determination of volatile nitrogenous compounds: ammonia, total volatile basic nitrogen, and trimethylamine. pp. 659-674. In: Ruiz-Capillas, C., Nollet, L.M.L., (Eds.); Flow Injection Analysis of Food Additives. CRC Press/Taylor and Francis Group: Boca Raton, FL, USA.

Qiu, X., Chen, S., Liu, G. \& Yang, Q. (2014). Quality enhancement in the Japanese sea bass (Lateolabrax japonicas) fillets stored at $4^{\circ} \mathrm{C}$ by chitosan coating incorporated with citric acid or licorice extract. Food Chemistry, 162: 156-160. https://doi.org/10.1016/j.foodchem.2014.04.037

Sallam, K.I.J. (2007). Antimicrobial and antioxidant effects of sodium acetate, sodium lactate, and sodium citrate in refrigerated sliced salmon. Food Control, 18(5): 566-575. https://doi.org/10.1016/j.foodcont.2006.02.002

Sathivel, S., Liu Q., Huang, J. \& Prinyawiwatkul, W. (2007). The influence of chitosan glazing on the quality of skinless pink salmon (Oncorhynchus gorbuscha) fillets during frozen storage. Journal of Food Engineering, 83(3): 366-373. https://doi.org/10.1016/j.jfoodeng.2007.03.009

Sayanjali, S., Ghanbarzadeh, B. \& Ghiassifar, S. (2011). Evaluation of antimicrobial and physical properties of edible film based on 
carboxymethyl cellulose containing potassium sorbate on some mycotoxigenic Aspergillus species in fresh pistachios. LWT - Food Science and Technology, 44(4): 1133-1138. https://doi.org/10.1016/j.lwt.2010.12.017

Sengor, G.F., Çelik, U., Akkus, S. (2000). Determination of freshness and chemical composition of scad (Trachurus trachurus, L. 1758) stored in refrigerator. Turkish Journal of Veterinary and Animal Sciences, 24(3): 187-194.

Shokri, S. \& Ehsani, A. (2017). Efficacy of whey protein coating incorporated with lactoperoxidase and $\alpha$-tocopherol in shelf life extension of Pike-Perch fillets during refrigeration. $L W T$ - Food Science and Technology, 85 (Part A): 225-231. https://doi.org/10.1016/j.lwt.2017.07.026

Socaciu, M.-I., Semeniuc, C.A. \& Vodnar, D.C. (2018). Edible films and coatings for fresh fish packaging: Focus on quality changes and shelf-life extension. Coatings, 8(10): 366. https://doi.org/10.3390/coatings8100366

Song, Y., Liu, L., Shen, H., You, J. \& Luo, Y. (2011). Effect of sodium alginate-based edible coating containing different antioxidants on quality and shelf life of refrigerated bream (Megalobrama amblycephala) Food Control, 22(3-4): 608615. https://doi.org/10.1016/j.foodcont.2010.10.012

Souza, B.W.S., Cerqueira, M.A., Ruiz, H.A., Martins, J.T., Casariego, A., Teixeira, J.A. \& Vicente, A.A. (2010). Effect of chitosanbased coatings on the shelf life of salmon (Salmo salar). Journal of Agricultural and Food Chemistry, 58(21): 1145611462. https://dx.doi.org/10.1021/jf102366k

Tejada, M. \& Huidobro, A. (2002). Quality of farmed gilthead seabream (Sparus aurata) during ice storage related to the slaughter method and gutting. European Food, Research and Technology, 215(1): 1-7. https://dx.doi.org/10.1007/s00217$\underline{002-0494-1}$

Ucak, I. (2019). Physicochemical and antimicrobial effects of gelatinbased edible films incorporated with garlic peel extract on the rainbow trout fillets. Progress in Nutrition, 21(1): 232240. https://dx.doi.org/10.23751/pn.v21i1.8222

Utami, R.K,. Nurhartadi, E., Putra, A.Y.T. \& Setiawan, A. (2004). The effect of cassava starch-based edible coating enriched with Kaempferia rotunda and Curcuma xanthorrhiza essential oil on refrigerated patin fillets quality. International Food Research Journal, 21(1): 413-419.

Valenzuela, C., Abugoch, L. \& Tapia, C. (2013). Quinoa proteinchitosan-sunflower oil edible film: mechanical, barrier and structural properties. LWT - Food Science and Technology, 50(2): 531-537. https://doi.org/10.1016/j.lwt.2012.08.010

Viuda, Martos, M., Ruiz, Navajas, Y., Fernández, López J., Pérez, \& Álvarez J.A. (2008). Antibacterial activity of different essential oils obtained from spices widely used in Mediterranean diet. International Journal of Food Science and Technology, 43(3): 526-531. https://doi.org/10.1111/j.1365-2621.2006.01489.x

Volpe, M., Siano, F., Paolucci, M., Sacco, A., Sorrentino, A., Malinconico, M. \& Varricchio, E. (2015). Active edible coating effectiveness in shelf-life enhancement of trout (Oncorhynchus mykiss) fillets. LWT - Food Science and Technology, $\quad \mathbf{6 0}(1)$ :

615-622. https://doi.org/10.1016/j.lwt.2014.08.048

Vásconez, M.B., Flores, S.K., Campos, C.A., Alvarado, J. \& Gerschenson, L.N. (2009). Antimicrobial activity and physical properties of chitosan-tapioca starch based edible films and coatings. Food Research International, 42(7): 762 769. https://doi.org/10.1016/j.foodres.2009.02.026

Wei, H., Wolf, G. \& Hammes, W.P. (2006). Indigenous microorganisms from iceberg lettuce with adherence and antagonist potential to use as protective culture. Innovative Food Science and Emerging Technologies, 7(4): 294-301. https://doi.org/10.1016/j.ifset.2006.02.002

Yıldız, P.O. \& Yanglar, F. (2016). Effects of different whey protein concentrate coating on selected properties of rainbow trout (Oncorhynchus mykiss) during cold storage $\left(4^{\circ} \mathrm{C}\right)$. International Journal of Food Properties, 19(9): 2007-2015. https://doi.org/10.1080/10942912.2015.1092160

Yu, D., Jiang, Q., Xu, Y. \& Xia, W. (2017). The shelf life extension of refrigerated grass carp (Ctenopharyngodon idellus) fillets by chitosan coating combined with glycerol monolaurate. International Journal of Biological Macromolecules, 101: 448-454. https://doi.org/10.1016/j.ijbiomac.2017.03.038

Zhou, R., Liu, Y., Xie, J. \& Wang, X. (2011). Effects of combined treatment of electrolysed water and chitosan on the quality attributes and myofibril degradation in farmed obscure puffer fish (Takifugu obscurus) during refrigerated storage. Food Chemistry, 129(4): 1660-1666. https://dx.doi.org/10.1016/j.foodchem.2011.06.028 